This is an electronic reprint of the original article. This reprint may differ from the original in pagination and typographic detail.

Author(s): Heikkilä, Marikka; Sajasalo, Pasi; Heikkilä, Jukka; Pohjola, Mikko

Title: Management dilemmas in innovative supplier networks

Year: $\quad 2016$

Version:

Please cite the original version:

Heikkilä, M., Sajasalo, P., Heikkilä, J., \& Pohjola, M. (2016). Management dilemmas in innovative supplier networks. International Journal of Procurement Management, 9(5), 616-635. https://doi.org/10.1504/ijpm.2016.078693

All material supplied via JYX is protected by copyright and other intellectual property rights, and duplication or sale of all or part of any of the repository collections is not permitted, except that material may be duplicated by you for your research use or educational purposes in electronic or print form. You must obtain permission for any other use. Electronic or print copies may not be offered, whether for sale or otherwise to anyone who is not an authorised user. 


\title{
Management dilemmas in innovative supplier networks
}

\section{Marikka Heikkilä*}

Centre for Collaborative Research, Turku School of Economics, University of Turku FI-20014 University of Turku, Finland

E-mail: marikka.heikkila@utu.fi

* Corresponding author

\section{Pasi Sajasalo}

Jyväskylä University, School of Business and Economics FI-40014 University of Jyväskylä

E-mail: pasi.sajasalo@jyu.fi

\section{Jukka Heikkilä}

Dept. of Management and Entrepreneurship, Turku School of Economics, University of Turku FI-20014 University of Turku, Finland

E-mail: jups@utu.fi

\section{Mikko Pohjola}

Centre for Collaborative Research, Turku School of Economics, University of Turku FI-20014 University of Turku, Finland

E-mail: mikko.pohjola@utu.fi

\begin{abstract}
This paper focuses on the challenges in managing innovation within supply networks. We present an empirical study on innovation collaboration between a focal company and its supply network of small and medium sized enterprises. By analysing the case from the viewpoints of the focal company, the suppliers and investors we point out three controversial issues in innovation management within the supply network: intellectual property rights, partnering versus competition, and commitment versus independency. Furthermore, we analyse the suppliers' positions with a purchasing portfolio model and present implications for innovation management practices in supply chains.
\end{abstract}

Keywords: supply management; innovation; co-innovation; collaboration; coopetition; supply chain; supply network; value network.

\section{Introduction}

Co-creation and collaboration between organisations is regarded as a necessity for competitive innovation in global markets (Chesbrough 2003; Christensen and Raynor, 2003; Prahalad and Ramaswamy, 2004; Vargo et al., 2008). Companies whose dominant thinking in strategic management used to be focused on core competences, lean and efficient supplier network (Cox, 1999; Prahalad and Hamel, 1990) are now attempting to create more value add to and within their value networks (Cai et al., 2014b) with increasingly automated production systems (Jovane et al., 2003). The perspective has been widened from production oriented supply chains to innovating value networks as part of business ecosystems (Kemppainen and Vepsäläinen, 2003; Moore, 1993, 1998). 
There is a vast literature pointing out benefits of co-creation (Prahalad \& Ramaswamy, 2000) and open innovation (Chesbrough, 2003) by sharing of knowledge resources and capabilities within and across organisational boundaries, especially with customers and suppliers (Allee, 2008; Huikkola et al., 2013; Teece, 2007). In many industries companies increasingly adopt the value network model where a focal firm takes the lead and acts as the main integrator of the design and production activities of the supply chain. Innovation within value network takes place in collaboration of several firms in different positions within the value stream (Christensen, 1997; Hobday et al., 2005). Companies in downstream positions traditionally compete for the deals of the focal firm, but more so in the recent decades, also participate in innovation collaboration (co-innovation) activities with their peers as well as together with the focal firm. Although the literature mentions the need for suitable supplier management practices, there is a gap in the body of knowledge, when it comes to the actual challenges and possible dilemmas in innovation collaboration in these kinds of value network setting. Especially, research considering the views of both the focal company and the suppliers are still scarce (Gassman et al., 2010). Therefore, there is imminent need to broaden the scope of innovation research towards change management (Van de Vrande et al., 2010) to realise the expected benefits from evolving collaboration (Prashant and Harbir, 2009; Ritala et al., 2013).

In this paper we examine the challenges of supply management in innovation collaboration between the leading focal company and its suppliers, small and medium sized enterprises (SMEs). Specifically, we ask the following research question: What are the main supply management challenges in co-innovation with a supplier network? We address the research question from three differing vantage points: the focal company, the suppliers (SMEs), and the investors (venture capitalists, VCs). We explore relationship management styles and cooperative routines that the parties encounter in their co-creation and innovation activities and utilise Kraljic's matrix (1983) to analyse the suppliers' relations with the focal company. The outset of the research is a situation where the focal company is attempting to shift its supply chain co-operation mode towards leadership of an innovative value network.

Our findings point out three major challenges in developing and managing co-innovation relationships in supply network: First, unresolved contractual and power asymmetry issues regarding intellectual property rights affect willingness of the network members to share knowledge, ideas or patents. Second, there is discrepancy between the aspirations of the top management for closer innovation partnership and everyday practices of the purchasing managers and buyers emphasising competitive bidding and efficient acquisitions with the very same partners. And third, the focal firm insist simultaneously a deeper commitment of the suppliers, and greater independency of the suppliers, which causes confusion, and hesitancy in SMEs' R\&D resource allocation for the co-innovation.

We start our paper with a review on some key theories. We then outline the research context and describe our research method, and then report our findings. These findings are discussed and their implications for innovation management practices in supply chains are considered. 


\section{Background to the research}

During the past decade of innovation research the collaborative and open aspect of innovation has received an increasing share of attention reflecting the fact that the closed within organisation mode of innovation has overwhelmingly been taken over by the open innovation mode in industries of all kinds (Chesbrough, 2003; Chesbrough and Crowther, 2006). This trend has led companies to focus on core competences and committing more to in-depth partnerships with selected partners (Cai et al., 2014a; Prahalad and Hamel, 1990). Within a network the focal firm has the central actor position and can shape the stability and development of the system (Iansiti and Levien, 2004). These focal companies are often large companies and have thousands of more specialised companies within their supply network.

\subsection{Purchasing portfolio models}

The firms leading the supplier networks have developed different types of relationships with their partners; some relationships rely on close cooperation, whereas others are more transaction based (Vanhaverbeke and Cloodt, 2008). Typically, decisions over the types of relationships depend on the frequency and specificity of the capabilities and resources that the suppliers provide the company, so that the higher the value generated for the company, the closer the relationship with the supplier (Gadde et al., 2010; Williamson, 1985).

Kraljic (1983) was the first to propose portfolio models into the purchasing relationships and it is still considered as the dominant approach in partner relationship management (Gelderman et al., 2003; Kahkonen, 2011; Viio and Grönroos, 2014; Ateş et al, 2015). Kraljic's approach is to optimise the dyadic relationships with suppliers by taking into account the capabilities of suppliers and the related risks. His matrix defines four types of purchases: non-critical (low risk, low impact), bottleneck (high risk, low impact), leverage (low risk, high impact), and strategic (high risk, high impact). It should be noted that several researchers point out that as the portfolios concern only dyadic relationships, the approach fails to cover more varied relations and interdependencies within supplier network (Dubois \& Pedersen, 2002), nor does it consider suppliers' side of the buyer-seller relationship or explicitly take into account the possible strategies and reactions of suppliers (Gelderman \& Van Weele, 2003). Moreover critique claims that portfolio approach is less suitable in context where the suppliers are taking part in product developing. On the other hand, a recent action research study by Nudurupati et al. (2015) show Kraljic's matrix was utilised in a global healthcare company to recognise from its supplier base those companies that had the potential to become value cocreation partners. Despite its deficiencies, the purchasing portfolio models (by Kraljic or similar) are still widely adopted in industry - the findings by Gelderman and Van Weele (2005) indicate that portfolio usage is indeed a sign of purchasing sophistication - they are easy to communicate and understand, and give practical guidelines for how to manage different purchasing situations and supplier relationships (Viio and Grönroos, 2014).

\subsection{Management of innovative supply networks}

Research on supply networks and innovations (Lamming et al., 2000; Gadde et al., 2010) indicate the intensifying role of networked innovations in the global economy. Innovation is defined as a multi stage process whereby organisations transform ideas into new or improved 
products or processes (Thompson, 1967), in order to advance, compete and differentiate themselves successfully in their marketplace (Baregheh et al., 2009). Many studies suggest that the locus of innovation is not the firm but rather the network or business ecosystem in which the firm is embedded (Afuah, 2000). For instance, LaRocca and Snehota (2014) suggest that the relationships within the partners are the locus where knowledge, on which the innovation process builds, is accessed, enacted and produced. The reasoning behind this is that as the essence of innovation is to produce solutions that combine previously unrelated elements in a novel way, interaction within the supply network is the key to attain tacit and context specific knowledge elemental to the innovation (Nonaka and Takeuchi, 1995). This approach is recognised in the use of such concepts as networks of learning (Powell et al., 1996), collaboration networks (Ahuja, 2000), open innovation (Chesbrough, 2003; 2006), and innovation networks (Dhanaraj and Parkhe, 2006).

Until recently, the literature on the management challenges and possible obstacles of innovation activities in value networks with small and medium size companies has been scarce (Gassman et al., 2010; Wynarczyk, et al., 2013). Many studies view management of co-innovation as a firm-level phenomenon (Kale et al., 2002; Walter et al., 2006), whereas, in order to understand the innovation within a value network it requires an approach that is explicit not only about the innovation challenges that are faced by the focal firm (Christensen, 1997; Cooper and Schendel, 1976; Henderson and Clark, 1990; Tushman and Anderson, 1986), but views it from the point of multiple actors (Gnyawali and Park, 2009; Ritala et al, 2013), including the focal firm, suppliers, competitors and investors, such as VCs providing funding for the new innovations. Focal companies have "the central actor position within the network that allows it to steer and orchestrate the innovation potential of the network towards joint value creation" (Ritala \& Huizingh, 2014), and reap the benefits of being big, as "large firms have powerful competitive advantages in all resource areas - money, people and interfirm relationships, among others. They are generally well-equipped to capitalise on emerging market opportunities, and will often do so aggressively." (Sinha and Noble, 2005, p.195). The literature suggests that the leading firm should coach the ecosystem (Doz, 1996) and the suppliers are expected to take active part in research and innovation. However, suppliers can - apart from the focal company - have also other customers, compete with each other, or may even belong to competing supplier networks. A central challenge in managing collaborations is that partners may have their own well-established processes, which may conflict (Davis and Eisenhardt, 2011). Innovating in these potentially coopetitive circumstances (Nalebuff and Brandenburger, 1996) increases the challenges in the orchestration of the R\&D relationships and knowledge sharing (Ritala and Tidström, 2014; Ritala et al., 2014).

Ritala et al. (2013) studied management mechanisms, which help to maintain, realise and deploy opportunities for value creation and capture. They separated the mechanisms for the management of the running innovation ecosystem from the ones utilised in its formation phase. The mechanisms included formal structures, such as schedules, platforms and forums (Ritala et al., 2013) as well as common guidelines, contracts, and Intellectual Property Rights ${ }^{1}$ (IPRs) concerning profits and appropriability (Dhanaraj and Parkhe, 2006). The

\footnotetext{
${ }^{1}$ In this article we use the term Intellectual Property Rights to include both industrial and immaterial rights.
} 
complementing intangible mechanisms, in particular inter-firm and inter-personal trust, was recognised as one of the most critical, success factor in collaborative settings. Other important intangible mechanisms were open communication and maintaining a common vision over time (Ritala et al., 2013). Smith et al. (2014) concluded that partners should identify and learn from the collaboration barriers in the ecosystem. Especially the smaller participants of a supply chain should focus on selection of practices and partners to achieve successful collaboration in innovation (Theyel, 2013). Even though innovation is praised in scientific literature, many aspects of innovation management practices especially related to change towards and challenges within innovation embracing value networks have not yet been studied.

\section{Research method and data collection}

Our research was initiated by an incubator company and a hub company. Their motivation for the research was to find out the reasons hampering the co-innovation within the supply network of the hub company. The incubator commissioned a group of researchers that had carried out several research studies on the focal company before, and thus were already familiar with the business context. The incubator set up a steering board for the project consisting of one manager from the incubator organisation, a managing director of one SME and a senior vice president of technology of the focal company.

Case-based approach was considered particularly relevant given the exploratory nature of this study (Dubois and Araujo, 2007)). The board governed our research project, approved our suggestion on the size and coverage of the empirical data set, helped in arranging access to the participating companies and in identifying the key informants to be interviewed. Additional interviewees were identified through applying a snowball method in which the interviewees indicated persons with whom they were conducting daily business activities within the network. The identified persons were then contacted for gaining additional data on the studied network relationships.

The case analysis required a collection of a considerable amount of data through primary sources such as interviews, and through secondary sources, such as previous research studies concerning the case companies (Applegate et al. 2004; Heikkilä et al, 2005, 2009; Heikkilä, 2010; Heikkilä and Heikkilä, 2010, 2013), official company documents, internal records and press releases to get the context for interpretation of the interviews. Multiple sources of data enabled cross checking of information through triangulation (Denzin and Lincoln, 2005). The primary source of our data comes from 17 face-to-face semi-structured theme interviews (Table 1). 13 were with the management and the persons responsible and most knowledgeable about the collaboration practises between the companies. In addition we interviewed four VCs. The interviews typically lasted two hours. Two or three researchers were present in each interview, except in the VC interviews, which were all carried out by one interviewer. Each interview was transcribed after the session by one of the researchers present at the interview situation to guarantee accuracy.

$--$

Add Table 1. Interviews around here

-- 
During the interviews, several memos were made regarding meta-information, including the emphasis, reactions and expressions of the interviewees, and key concepts being discussed. The search for new interviews and other data sources stopped only when saturation was reached (Glaser \& Strauss, 1967), i.e., the last interviewees could not provide any new insights (or new documents that might lead to new insight). Prior to the interviews, a case study protocol and an interview protocol were developed to guarantee research reliability (Yin, 2009). As suggested by Yin (2009), the protocol consisted of five sections: the purpose of the study, data collection, report outline, semi-structured questions and evaluation. All interviews were recorded and transcribed. The transcribed interviews were checked by the interviewed, at the same time same clarifying questions may have been asked.

To ensure that no valuable information had eluded the interviewer's attention, all researchers taking part in this study, analysed the data in a systematic way using Nvivo, a qualitative data research software, and analysis approach proposed by Miles and Huberman (1994). First a long-list of quotes was selected from the interview transcripts, explaining or indicating an actual or potential source of misalignment in innovation relationships (Miles \& Huberman, 1994). Then, in an inductive way, all the quotes were reviewed, which led to more quotes and the identification of the challenges from the differing viewpoints of the interviewed actors. In this phase, the authors attempted to scrutinise the data, to reveal the discrepancies and the underlying causes. The authors reviewed each other's codes and discussed the concepts to be coded, the naming of the codes and the levels of detail. Finally, the authors identified patterns of codes (Miles \& Huberman 1994, p. 69) yielding to three factors affecting the innovations relationship within the empirical case. These three factors are described in the results section of this paper. Furthermore, we analysed the findings to explain supplier positions against Kraljic's purchasing portfolio (Kraljic, 1983), and verified our interpretation with the participants and industry representatives.

The final results of the research were presented to the board and the participating companies for verification of the instrument and context validity. Another technique we have applied to improve the relevance and context validity of this research was to present and discuss the results with a wider audience consisting of the companies acting within the same or similar ecosystems. The corrections made in this review process increase the internal validity and also the usefulness of the results in the problem situation of the study (Iversen, 2007). Finally, this article was written on the basis of final report accepted by the board and distributed to all participating companies. For the above reasons we are quite confident about the validity of our research. We also have set up a study database (see e.g. Miles and Huberman, 1994), which includes all the study notes, study documents such as interview tapes and transcribes, and secondary data collected during this research, as well as a list of direct quotes from transcribed interviews related to in the reported findings this study.

\section{The Case}

The focal company (Hub) is a high-technology machinery corporation operating in global markets. It has over 29,000 employees in more than 50 countries. For years it has been the leading supplier of investments goods in its own worldwide segment and is considered the technology leader in its field. The net sales are around EUR 5,600 million. The Hub, typical to technology industry in general, is highly focused on its core competencies. It has aimed at long-term development of subcontracting since 1990's (Hub, 2006). The Hub has total 20000 
suppliers and the subcontracting purchases amount $65 \%$ of company's net sales. As supplier network carries out more than half of the production, its competence and progress is of great importance to the Hub's business.

We interviewed the representatives of Hub, five SMEs and four VCs. The SMEs were suppliers of the Hub (Table 2). The SME-e was also a supplier and at the same time competitor of SME-c. The SMEs are considerably smaller measuring in net sales and in number of personnel. In addition to the companies that are producing and innovating products and services within the ecosystem, we also interviewed four Venture capitalist (VC) firms who provide funding for companies.

$--$

Add Table 2. Case companies around here

$-$

\section{Findings}

According to the research data the key driver for the supply network's profitable growth strategy is considered to be innovations and R\&D that are carried out in close cooperation between the Hub, customers, and subcontractors. The espoused strategy of the CEO of the Hub is that the company will concentrate its increasing purchases to fewer suppliers. The aim is to move towards partnerships, but also to have enough competing suppliers to guarantee the best supply of complementary components in all circumstances. The partners are expected to take larger responsibility in the value chain, and to deliver larger modules together with their own net of subcontractors. The CEO also expects the SMEs to become more innovative in improving the products and modernising production technologies.

The Hub has dedicated advisors who travel around at the partners' premises for guiding, teaching and interacting with the partners. Once a year the Hub organises a "Supplier Day", where to approximately 100 suppliers are invited to join, discuss and share their views on topical matters. The Hub also nominates one of them as the supplier of the year. It evaluates the quality of partners by their productive capacity, quality, delivery reliability and price development. However, they are increasingly using "soft" metrics, such as ability to cooperate, innovativeness and communication.

Despite the strategy and efforts of the Hub towards more co-creation and co-innovation, the network was not fully satisfied with the current situation. Building on the analysis of the research data, we found three key factors to affect the co-innovation ability of the ecosystem. These issues are described next in more detail.

\subsection{Intellectual property rights}

The Figure 1 below presents the interviewees' views on the importance of intellectual property rights (IPRs) to the innovation capacity of the value chain. The VCs saw that R\&D collaboration is important to the competitiveness of the business, but there is too much emphasis on technology (i.e., too little on business design). They were strict on settling all the IPR issues within the supply network in advance, before funding the co-operation. The Hub insisted on having the IPRs of all the R\&D it has funded and provided market access, but it 
could grant the cooperating supplier with a licence, which allows it to sell or modify the innovation to other industries or to limited customer segments.

SMEs in turn find the attitude of the Hub to limit their willingness to commit to joint $R \& D$, if the rights are owned by the Hub, and licensed back on case-by-case basis. They ask why they should invest in R\&D if they are not benefitting immediately from it. The Hub admits that the innovation capacity of the network is under-utilised due to the lack of trust regarding the rights ownership ambiguity and uncertainty to innovative ideas.

$--$

Add Figure 1. IPR challenges around here

\subsection{Balance between partnership and competition}

Figure 2 illustrates the contradiction between partnering and short-term contractual arrangements, such as constant bidding. VCs view builds on the faith on competitive markets, survival of the fittest in the beauty contest to partnership as the boosting force to innovativeness in R\&D, products, services and operations. SMEs saw the both sides of the coin: they admitted that competition drives them towards improvement and efficiency, but asked how could a supplier company investing in R\&D compete with its cost-leadership rivals that are not expected to put so much effort in relationship specific investments and transaction costs of co-operation with the Hub. Commercialisation of leading edge technology takes also substantial time, and then funding can become a bottleneck limiting the cooperation.

The convergence gap between the Hub's strategy and its daily practices of procurement was heavily criticised by some of the SMEs. The practise of constant bidding of the Hub's purchasing department forced them to cut down innovation activities and to prioritise cost competitiveness instead. As a resolution they suggested the Hub to reorganise its purchasing categories and organisation so that innovations and future features would be accounted for higher value, not only for the lowest price.

Add Figure 2. Partnering vs. Competition around here

\subsection{Balancing between being committed and independent}

Figure 3 illustrates the parallel needs for deep commitment to the supply chain co-operation and simultaneously to maintaining companies' independency. VCs seemed to more vote for independency, because larger customer base and new potential markets would improve the value of the company more that high commitment to one hub, which is also considered a risky strategy. VCs were somewhat suspicious on the Hubs motivation to support suppliers outside 
the Hub's own ecosystem. The Hub saw this issue as an optimisation problem between risks and costs. Often the Hub expected high commitment from its suppliers, especially from its 1st tier partners. On the other hand, the Hub became concerned, if the supplier was too vulnerable on the volatility of the Hub's orders. Therefore, the Hub avoided the risk of highly dependent suppliers by finding competing suppliers, and by urging their suppliers to find new customers in other business segments.

Most often, the resources, time and information set the limits to the operations of the SME suppliers. They were well aware of the possibility that they could easily be replaced in the value network, if not within months, but at least within couple of years. In order to keep up with the development of the industry they should commit their R\&D resources to serve the business segment of their most important customer, i.e. the Hub. However, at the same time they should look for new customers for their present and future technology. Also the transferability of the technology can limit the expansion of the customer base. If it is not transferable as such, SMEs must decide where to put their development resources: on the development of Hub's product line, or on new potential application areas.

SMEs felt that Hub was not providing help in this issue. To the contrary, since the Hub did not approve that its suppliers would start competing with it in its own business segment, they expected that SMEs find new customers from a different industry or from a specific niche, which again requires from SMEs substantial resourcing to find and adapt to new customers. An extreme example of the effects of this contradiction is what happened to SME-d shortly after our data collection period: SME-d had developed innovative solutions that Hub considered as being competitive to its own products. Hub was, though, interested in finding collaboration arrangement in selling the solution as part of its own offering. However, when the SME-d started to provide the solution directly to some customers and rivals of Hub, the collaboration negotiations were disrupted. Finally, the SME-d went into bankruptcy and the focal company bought the remaining property. This example exposes the dark side of management of innovation and competition within value networks.

Add Figure 3. Commitment vs. Autonomy around here

\subsection{Purchasing portfolio and strategy shifts}

Focal companies have found purchasing portfolio management frameworks (e.g. Kraljic, 1983) efficient to manage their supply chains (Viio and Grönroos, 2014; Gelderman et al., 2003) in terms of reducing vulnerability and maximizing purchasing power on suppliers. As implied by the previous findings, a supplier network with several co-operating and at the same time competing partners would call for other ways of governing the services and innovation development.

We illustrate our view with the case SMEs on Kraljic's matrix (Fig. 4.). SME-e was categorised as non-critical supplier and its aim was to reduce its dependency on the Hub further, towards more balanced set of focal companies and customers. SME-a, SME-b and 
SME-c were all strategic partners to the Hub. However, SME-b had already made the decision to divide the company in two parts. SME-b1 was to continue as more strategic supplier for the Hub and SME-b2 to be considered low-risk partner to the Hub, freer to do business in potential future product areas. SME-c, noticed that regardless of its strategic partner status, the purchaser's of Hub were constantly exerting their power for tighter bids. Yet, SME-c was officially committed in acting as an innovating first tier integrator - there was a discrepancy between expected and realized relationship of SME-c. SME-d, which was considered partially competing with the Hub with its innovations, eventually filed in for bankruptcy, and the Hub acquired its patents.

We conclude that the innovative capacity of the network was vulnerable to the Hub exerting its purchasing power, which reduced the available resources and motivation for innovations in SME-c. As an antidote, SME-b split its operations in two, arms-length innovative SME-b1, and competitive SME-b2, adjusting to the Hub's practised strategy. When SME-d was trying to maintain its independence, it lost its interdependent strategic position in relation with the Hub as the main customer, and ran out of business.

\section{Add Figure 4. The suppliers position in the Kraljic's matrix around here}

\section{Discussion and conclusions}

The strategic principles guiding the way how supply management is conducted and operationalised influence significantly on the ability of the companies to utilise the innovation potential of their value network. Our empirical study describes this task is not an easy one. Especially, it shows that the transformation towards co-innovating supply network has pitfalls, which may hinder or even prevent capitalising the benefits. The challenges found in our empirical study are rather fundamental requiring the management to take explicit stance on the ownership of ideas and of customers as well as on the responsibility over development of the business regarding their supply network:

\section{Open vs. closed intellectual property rights strategy}

Both the Hub and the SMEs recognised the need to develop the practices and procedures related to IPR. The practises should motivate the parties to share their new ideas within the network without the fear of losing the ownership to the idea. The challenge was to find ways to improve the trust in the value network in this matter. VCs' prerequisite for funding is agreement on IPRs, and preferably more emphasis on business issues than technology in the future.

\section{Partnering vs. competition}

Even though the Hub's espoused strategy is to have a closer relationship with a smaller set of partners, SMEs realised that their offerings were mostly assessed by price-related criteria leaving aside the innovation aspect. They felt this unfair, since they had made asset specific investments for instance in $R \& D$, environmental protection and quality systems to meet their partner status requirements. This involves additional transaction 
costs of cooperating and, as a consequence, makes it difficult to compete with price. Thus, the SMEs claimed that there is apparent divergence between the strategy espoused of the Hub and the strategy practiced in purchasing. This jeopardizes the willingness and resources needed for co-operation among the network partners.

\section{Commitment vs. independency}

It is considered vital for SMEs to develop their products to suit several industries or business segments, because this would also benefit the Hub - too dependent supplier becomes a risk to the Hub. In order to keep up with the development of the high-tech products and services, suppliers should constantly invest in special, reciprocal know-how and product development. For SMEs this causes allocation problems in R\&D due to their limited resources, and in funding, because VCs strongly favour avoidance of too dependent relationships. The Hub needs to have complementary suppliers to reduce the vulnerability of the supply chain, and the SMEs should decide whether to rely on the Hub in helping them to diversify their customer portfolio, or to actively form an arms-length relationship with the hub.

To benefit from the innovative capacity of the network the supply management mechanisms should promote a more cooperative approach. The managerial implications from our analysis of the suppliers' position with Kraljic's matrix is that to increase innovation capacity of the network, the suppliers should be categorised according to known criteria and the supplier status should be effectively communicated and implemented throughout the network (Caniels and Gelderman, 2005). Also, it is important to share mandate for R\&D across the network to those with best expertise dynamically: networks and business evolve over time and network roles change, also suppliers have aspirations to actively change their position for their benefit, as our case shows. Furthermore, Kraljic's matrix is not well suited to products and services being developed and run together with partner organizations; As Dubois and Pedersen (2002) point out, when using Kraljic's matrix, the productivity and innovation capacity through multi partner relations may stay uncovered. Against this backdrop VCs request for more business than technology development becomes evident, even in such high-tech area. The first practical step towards this direction is to tackle the divergence between strategic espoused and practiced within the focal organisation. The present discrepancy stems from different interpretations and unsuitable incentive schemes at the focal organisation. For instance, buyers dealing with first tier suppliers and R\&D partners would promote long-term development and collaboration instead of short term price cuts.

As a scientific contribution, we continue the discussion on the management of co-innovation within value networks (Gassman et al., 2010; Ritala et al., 2013, 2014; Ritala and Huizingh, 2014; Ritala, P. and Tidström, 2014; Wynarczyk, et al., 2013; Theyel, 2013). By studying the Hub's practiced strategy also by interviewing the SMEs and VCs on their co-innovation management views, we could bring the most controversial issues of innovation networks to light. Our study resonates with Vanhaverbeke and Cloodt (2008) on how management has to balance between contradictory goals in pursuit of networked innovation. Christensen (1997) points out how innovative capacity of companies is harnessed by the risk of loss of loyal customer base. Simultaneously the companies think they have to create better products for their customers in order to maintain their competitive position. They get stuck with "sustaining technology strategy", i.e. bringing better products onto established markets. This leads to the well-known dilemma (Norman, 1998): continuing to improve products further, 
the extra performance of which is not really valued by the customers. Hence, the hub company and its partners can easily become vulnerable to product/market disruptions of the entrants. As Eppinger and Vladova (2013) and Smith et al., (2014) point out, the innovating network is better to have a balanced strategy for closed and open innovation in order to avoid the dilemma by thinking out-of-the-box' instead. This is why VCs demanded for diversification of risk, and why the Hub preferred to have innovative suppliers with diversified enough customer bases. The contradiction rose from the fact that this espoused strategy did not realise and made the suppliers to react to the practised strategy. As a result, the co-innovation in the supply network lost momentum.

To conclude, this article identifies some main challenges in management of innovative supply networks. By analysing an empirical case of network geared towards high-tech innovations from the viewpoints of the Hub, the SMEs and VCs, we bring out three most challenging issues of networked innovation: open vs. closed intellectual property rights strategy, partnering vs. competition, and commitment vs. independency and what kind of strategic shifts these caused in SMEs in relation to the Hub.

This study has its shortcomings and limitations. It is based on 17 interviews and provides insight to one empirical case. Further follow up case studies and surveys are necessary for generalisation and accumulation of the scientific body in the area of innovation and supply management.

\section{References}

Afuah, A. (2000) 'How much do your co-opetitors' capabilities matter in the face of technological change?', Strategic Management Journal, Vol. 21 No. 3, pp.387-404

Ahuja, G. (2000) 'Collaboration networks, structural holes, and innovation: A longitudinal study', Administrative science quarterly, Vol. 45 No. 3, pp.425-455

Allee, V. (2008) 'Value network analysis and value conversion of tangible and intangible assets', Journal of Intellectual Capital, Vol. 9 No. 1, pp.5-24

Applegate L. M., Heikkilä M. and Lyytinen K. (2004) 'Metso Paper: Globalization of Finnish Metal Workshops', Harvard Business School Case 9-805-057, 30 pages.

Ateş, M. A., Wynstra, F., and van Raaij, E. (2015) 'An exploratory analysis of the relationship between purchase category strategies and supply base structure', Journal of Purchasing and Supply Management, available online 1 May 2015 doi:10.1016/j.pursup.2015.04.007

Baregheh, A., Rowley, J., and Sambrook, S. (2009) 'Towards a multidisciplinary definition of innovation', Management Decision, Vol. 47, pp.1323-1339

Cai, J., Smart, A. U. and Liu, X. (2014a) 'Innovation exploitation, exploration and supplier relationship management', International Journal of Technology Management, Vol. 66 No. 2, pp.134-155

Cai, H., Chen, H., Li, Y. and Liu, Y. (2014b) 'External dynamic capabilities, reconfiguration of cooperation mechanism and new product development: contingent effect of technological resource base', International Journal of Technology Management, Vol. 65 No.1, pp.240-261

Caniels, M. C. and Gelderman, C. J. (2005) 'Purchasing strategies in the Kraljic matrix-A power and dependence perspective', Journal of Purchasing and Supply Management Vol 11 No 2, pp.141-155. 
Chesbrough, H. (2003) 'The Era of Open Innovation', MIT Sloan Management Review, Spring 2003.

Chesbrough, H. (2006) Open Business Models: How to Thrive in the New Innovation Landscape, Boston: Harvard Business Press.

Chesbrough, H. and Crowther, A.K. (2006) 'Beyond high tech: early adopters of open innovation in other industries', $R \& D$ Management, Vol. 36 No. 3, pp.229-236

Christensen, C.M. (1997) The Innovator's Dilemma: When New Technologies Cause Great Firms to Fail, HarperBusiness.

Christensen, C. M. and Raynor, M. E. (2003). The innovator's solution. Harvard Business Press.

Cooper, A. C. and Schendel, D. (1976) 'Strategic responses to technological threats', Business horizons, Vol. 19 No. 1, pp.61-69

Cox, A. (1999) 'Power, value and supply chain management', Supply Chain Management: An International Journal, Vol. 4 No. 4, pp.167-175

Dhanaraj, C. and Parkhe, A. (2006) 'Orchestrating innovation networks', Academy of Management Review, Vol. 31 No. 3, pp.659-669

Davis, J. P. and Eisenhardt, K. M. (2011) 'Rotating Leadership and Collaborative Innovation Recombination Processes in Symbiotic Relationships', Administrative Science Quarterly, Vol. 56 No. 2, pp.159-201

Denzin, N. and Lincoln, Y. (Eds.), (2005) The Sage handbook of qualitative research. Sage.

Doz, Y.L. (1996) 'The evolution of cooperation in strategic alliances: initial conditions of learning processes', Strategic Management Journal, Summer Special Issue, 17, pp.5583

Dubois, A. and Araujo. L. (2007) 'Case research in purchasing and supply management: opportunities and challenges', Journal of Purchasing and Supply Management, Vol. 13 No. 3, pp. 170-181.

Dubois, A. and Pedersen, A. C. (2002) 'Why relationships do not fit into purchasing portfolio models - a comparison between the portfolio and industrial network approaches', European Journal of Purchasing \& Supply Management, Vol 8 No 1, pp. 35-42.

Eppinger, E. and Vladova, G. (2013) 'Intellectual property management practices at small and medium-sized enterprises', International Journal of Technology Management, Vol. 61 No.1, pp.64-81

Gadde, L. E., Håkansson, H., \& Persson, G. (2010). Supply Networks Strategies. John Wiley $\&$ Sons. Ltd, Chichester.

Gassman, O., Enkel, E. and Chesbrough, H. (2010) 'The future of open innovation', $R \& D$ Management, Vol. 40 No. 3, pp.213-221

Gelderman, C. J., and Van Weele, A. J. (2005) 'Purchasing portfolio models: a critique and update', Journal of Supply Chain Management, Vol. 41 No. 3, pp.19-28.

Gelderman, C. J. and Van Weele, A. J. (2003) 'Handling measurement issues and strategic directions in Kraljic's purchasing portfolio model', Journal of purchasing and supply management, Vol. 9 No. 5, pp.207-216

Glaser, B.G. and Strauss, A.L. (1967) The discovery of grounded theory: strategies for qualitative research, Aldine Transaction: A Division of Transaction Publishers, New Brunswick (USA) and London (UK).

Gnyawali, D. R. and Park, B. J. R. (2009) 'Co-opetition and Technological Innovation in Small and Medium-Sized Enterprises: A Multilevel Conceptual Model', Journal of Small Business Management, Vol. 47 No. 3, pp.308-330 
Heikkilä J., Heikkilä M. and Lehmonen, J., (2005) 'Sharing for understanding and doing for learning: An Emerging Learning Business Network', ICFAI Journal of Knowledge Management, Vol 3, No. 1, pp. 28-45

Heikkilä, J., Heikkilä, M., Lehmonen, J. and Pekkola, S. (2005) 'Smart ICT Support for Business Networks', in Vervest, P.H.M, Heck, E.v., Preiss, K., Pau, L.-F. (Eds.) Smart Business Networks, Springer, p. 389-404

Heikkilä, M. (2010) 'Coordination of complex operations over organisational boundaries', Diss. thesis, University of Jyväskylä, Jyväskylä Studies in Computing 111.

Heikkilä, M. and Heikkilä, J. (2013) 'Collaborative Business Model Innovation Process for Networked Services', In Järveläinen, J., Li, H., Tuikka, A-M. and Kuusela, T. (Eds.), Co-created Effective, Agile, and Trusted eServices, Lecture Notes in Business Information Processing Vol. 155, pp. 133-147

Heikkilä, M. and Heikkilä, J. (2010) 'Conscription of Network Business Models', The IUP Journal of Business Strategy, Vol. 7, No. 4, pp. 7-23

Heikkilä, M., Sajasalo, P. and Heikkilä, J. (2009) 'Trouble in paradise: a case of a technology industry supply network', in $9^{\text {th }}$ EBRF conference Emergent drivers of shared business models in globalizing ecosystems, Sept 23 - 25 2009, Jyväskylä, Finland.

Henderson, R. M., and Clark, K. B. (1990) 'Architectural innovation: the reconfiguration of existing product technologies and the failure of established firms', Administrative science quarterly, 9-30.

Hobday, M., Davies, A. and Prencipe, A. (2005) 'Systems integration: a core capability of the modern corporation', Industrial \& Corporate Change, Vol. 14 No. 6, pp. 1109-1143

Hub (2006) 'Production subcontracting - one of the corner stones of Hub's success', A presentation in a seminar. 30.11.2006.

Huikkola, T., Ylimäki, J. and Kohtamäki, M. (2013) 'Joint learning in R\&D collaborations and the facilitating relational practices', Industrial Marketing Management, Vol. 42 No. 7, pp.1167-1180

Iansiti M. and Levien R. (2004) Keystone Advantage: What the New Dynamics of Business Ecosystems Mean for Strategy, Innovation, and Sustainability, Harvard Business School Press Books.

Jovane, F., Koren, Y. and Böer C.R. (2003) 'Present and Future of Flexible Automation: Towards New Paradigms', CIRP Annals - Manufacturing Technology, Vol. 52 No. 2, pp.543-560

Iversen, J. (2007) 'IS action research and its criteria'. In N. Knock (Ed.), Information Systems Action research: An applied view of emerging concepts and methods, Springer, pp.355-376.

Kahkonen, A. K. (2011) 'Power relations in supply strategies-a network approach', International Journal of Procurement Management, 4(4), pp.386-401.

Kale, P., Dyer, J. H. and Singh, H. (2002) 'Alliance capability, stock market response, and long term alliance success: the role of the alliance function', Strategic Management Journal, Vol. 23 No. 8, pp.747-767

Kemppainen, K. and Vepsäläinen, A.P.J. (2003) 'Trends in Industrial Supply Chains and Networks'. International Journal of Physical Distribution and Logistics Management, Vol. 33 No. 8, pp.701-709.

Kraljic, P. (1983) 'Purchasing must become supply management', Harvard Business Review, Vol. 61 No. 5, pp. 109-117

La Rocca, A. and Snehota, I. (2014) 'Relating in business networks: Innovation in practice'. Industrial Marketing Management, Vol. 43 No. 3, pp. 441-447. 
Lamming, R., Johnsen, T., Zheng, J., and Harland, C. (2000), 'An initial classification of supply networks', International Journal of Operations \& Production Management, Vol. 20 No. 6, pp. 675-691.

Miles, M.B. and Huberman, A.M. (1994) Qualitative data analysis: An expanded sourcebook, Sage Publications, 2nd ed.

Moore, J., (1993) 'Predators and Prey: A New Ecology of Competition', Harvard Business Review, May/June 1993.

Moore, J. (1998) 'The Rise of a New Corporate Form', Washington Quarterly, Vol. 21 No.1, pp.167-181

Nalebuff, B. and Brandenburger, A. (1996) Co-opetition, Profile Books.

Nonaka, I. and Takeuchi, H. (1995) The knowledge creating company, Oxford University press.

Norman, D. (1998) The Invisible Computer: Why good products can fail, the personal computer is so complex and information appliances are the solution, MIT Press, London, England.

Nudurupati, S., Bhattacharya, A., Lascelles, D., and Caton, N. (2015) 'Strategic sourcing with multi-stakeholders through value co-creation: An evidence from global health care company', International Journal of Production Economics, Available online 23 January 2015. http://dx.doi.org/10.1016/j.ijpe.2015.01.008i

Powell, W. W., Koput, K. W. and Smith-Doerr, L. (1996) 'Interorganizational collaboration and the locus of innovation: Networks of learning in biotechnology', Administrative science quarterly, pp.116-145.

Prahalad, C. K. and Ramaswamy, V. (2000) 'Co-opting customer competence', Harvard business review, Vol. 78 No. 1, pp.79-90

Prahalad, C. K. and Ramaswamy, V. (2004) 'Co-creation experiences: The next practice in value creation', Journal of interactive marketing, Vol. 18 No. 3, pp.5-14

Prahalad, C. K. and Hamel, G. (1990) 'The Core Competence of the Corporation', Harvard Business Review, Vol. 68 No. 3, pp.79-91

Prashant, K. and Harbir, S. (2009) 'Managing strategic alliances: what do we know now, and where do we go from here?', The Academy of Management Perspectives, Vol. 23 No. 3, pp.45-62

Ritala, P., Agouridas, V., Assimakopoulos, D. and Gies, O. (2013) 'Value creation and capture mechanisms in innovation ecosystems: a comparative case study', International Journal of Technology Management, Vol. 63 No. 3, pp.244-267

Ritala, P. and Huizingh, E. (2014) 'Business and network models for innovation: strategic logic and the role of network position', International Journal of Technology Management, Vol. 66 No. 2, pp.109-119

Ritala, P., Olander, H., Michailova, S. and Husted, K. (2014) 'Knowledge sharing, knowledge leaking and relative innovation performance: An empirical study'. Technovation.

Ritala, P. and Tidström, A. (2014) 'Untangling the value-creation and value-appropriation elements of coopetition strategy: A longitudinal analysis on the firm and relational levels', Scandinavian Journal of Management.

Sinha, R.K. and Noble, C.H. (2005) 'A model of market entry in an emerging technology market', IEEE Transactions on Engineering Management, Vol. 52, No. 2, pp.186-98

Smith, D., Alshaikh, A., Bojan, R., Kak, A. and Manesh, M. M. G. (2014) 'Overcoming Barriers to Collaboration in an Open Source Ecosystem', Technology Innovation Management Review, Vol. 4, January 2014. 
Theyel, N. (2013) 'Extending open innovation throughout the value chain by small and medium-sized manufacturers', International Small Business Journal, Vol. 31 No 3, pp.256-274

Teece, D. J. (2007) 'Explicating dynamic capabilities: the nature and microfoundations of (sustainable) enterprise performance', Strategic management journal, Vol. 28 No. 13, pp. 1319-1350.

Thompson, J. D. (1967) Organizations in Action: Social Science Bases in Administrative Theory, McGraw-Hill, New York.

Tushman, M. L. and Anderson, P. (1986) 'Technological discontinuities and organizational environments', Administrative science quarterly, pp.439-465

Van De Vrande, V., Vanhaverbeke, W. and Gassmann, O. (2010) 'Broadening the scope of open innovation: past research, current state and future directions', International Journal of Technology Management, Vol. 52 No. 3, pp.221-235

Vanhaverbeke, W. and Cloodt, M. (2008). 'Open innovation in value networks', in Chesbrough, H., Vanhaverbeke, W., West, J. (eds.), Open Innovation: Researching a New Paradigm, Oxford University Press, UK, 2006, pp. 258-284.

Vargo, S. L., Maglio, P. P. and Akaka, M. A. (2008) 'On value and value co-creation: A service systems and service logic perspective', European management journal, Vol. 26 No. 3, pp.145-152

Viio, P. and Grönroos, C. (2014) 'Value-based sales process adaptation in business relationships', Industrial Marketing Management

Walter, A., Auer, M. and Ritter, T. (2006) 'The impact of network capabilities and entrepreneurial orientation on university spin-off performance', Journal of Business Venturing, Vol. 21 No. 4, pp.541-567

Williamson, O.E. (1985) The Economic Institutions of Capitalism; Firms, Markets, Relational Contracting, The Free Press, New York, NY.

Wynarczyk, P, Piperopoulos, P and McAdam, M. (2013), 'Open Innovation in SMEs: Special Issue Overview' International Small Business Journal, Vol. 31 No. 3, pp.240-255

Yin, R.K. (2009) Case study research: design and methods, Sage Publications, Inc. 4th Ed. 
Table 1. Interviews

\begin{tabular}{|c|c|c|}
\hline Company & Interviewees & Main task \\
\hline \multirow[t]{6}{*}{ Focal Company } & Management & Vice President, Sourcing \\
\hline & Management & $\begin{array}{l}\text { Senior Vice President, Technology } \\
\text { coordination and property rights }\end{array}$ \\
\hline & Management & Senior business advisor \\
\hline & Operation level & Sourcing and logistics \\
\hline & Operation level & R\&D, New technology development \\
\hline & Operation level & Long term supplier relationships, contracting \\
\hline Focal company's sister company & Management & Vice President, R\&D \\
\hline SME-a & Management & Managing Director \\
\hline SME-b & Management & Managing Director \\
\hline \multirow{2}{*}{ SME-C } & Management & Managing Director \\
\hline & Operation level & $\begin{array}{l}\text { Responsible for relations with the Focal } \\
\text { company }\end{array}$ \\
\hline SME-d & Management & Managing Director \\
\hline SME-e & Management & Managing Director \\
\hline VC1 & Management & Senior Advisor \\
\hline VC3 & Management & Head of investments \\
\hline VC3 & Management & Managing Director \\
\hline VC4 & Management & Senior Partner \\
\hline Total 11 companies & & 17 interviewees \\
\hline
\end{tabular}

Table 2. Case companies

\begin{tabular}{|c|c|c|c|c|c|c|}
\hline & SME-a & SME-b & SME-C & SME-d & SME-e & Hub \\
\hline Net sales (1000 EUR) & 1200 & 11000 & 9000 & 8700 & 21000 & 5600000 \\
\hline No. of personnel & 16 & 105 & 42 & 30 & 200 & 29000 \\
\hline $\begin{array}{l}\text { Role in the business } \\
\text { ecosystem }\end{array}$ & $\begin{array}{r}\text { Supplier of the } \\
\text { Hub }\end{array}$ & $\begin{array}{r}\text { Supplier of the } \\
\text { Hub }\end{array}$ & $\begin{array}{r}1 \text { st tier } \\
\text { supplier }\end{array}$ & $\begin{array}{r}\text { Supplier of } \\
\text { the Hub }\end{array}$ & $\begin{array}{r}\text { Supplier of } \\
\text { the hub and } \\
\text { SME-c, also } \\
\text { competitor of } \\
\text { SME-c }\end{array}$ & \\
\hline $\begin{array}{l}\text { Main products \& } \\
\text { services }\end{array}$ & $\begin{array}{r}\text { computational } \\
\text { technology } \\
\text { based } \\
\text { services, } \\
\text { modelling and } \\
\text { simulation }\end{array}$ & $\begin{array}{r}\text { high-quality, } \\
\text { high-tech } \\
\text { products, } \\
\text { systems and } \\
\text { services }\end{array}$ & $\begin{array}{r}\text { automation } \\
\text { solutions for } \\
\text { industrial } \\
\text { companies \& } \\
\text { equipment } \\
\text { manufacturers }\end{array}$ & $\begin{array}{r}\text { machine } \\
\text { vision } \\
\text { solutions } \\
\text { for } \\
\text { industrial } \\
\text { processes }\end{array}$ & $\begin{array}{r}\text { Installation } \\
\text { and } \\
\text { assembly } \\
\text { projects and } \\
\text { mechanical } \\
\text { maintenance. }\end{array}$ & $\begin{array}{r}\text { high } \\
\text { technology } \\
\text { machinery, } \\
\text { automation } \\
\text { and } \\
\text { services }\end{array}$ \\
\hline
\end{tabular}




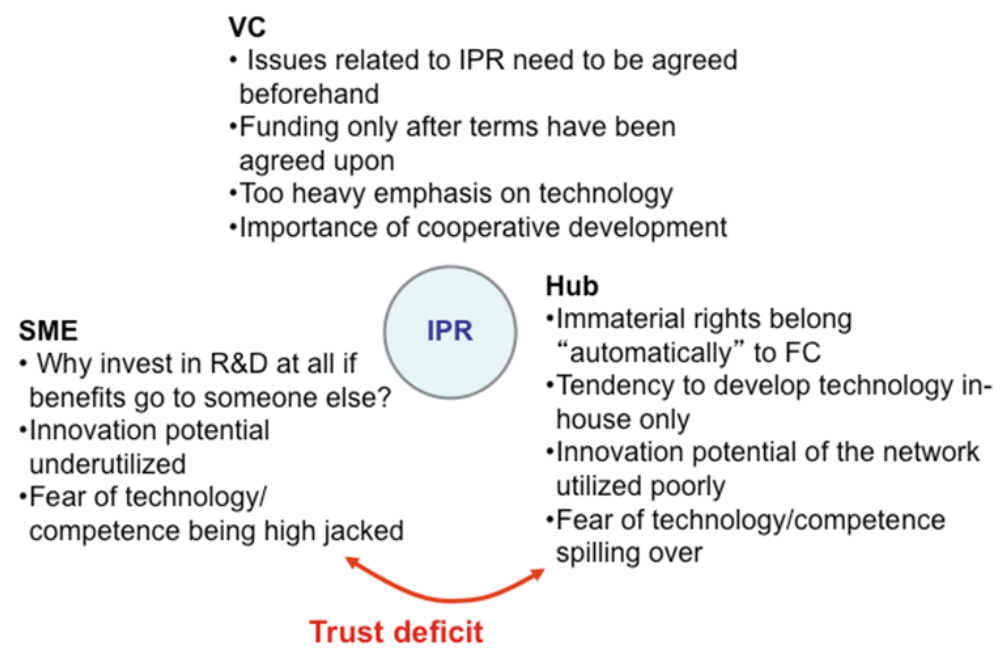

Figure 1. IPR challenges

Trust deficit

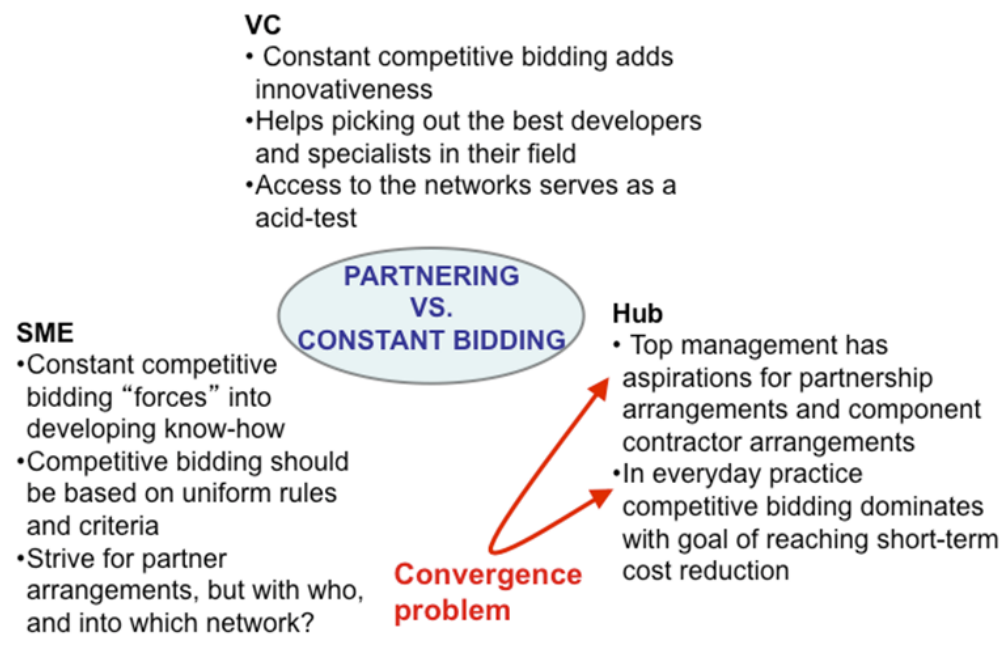

Figure 2. Partnering vs. Competition 


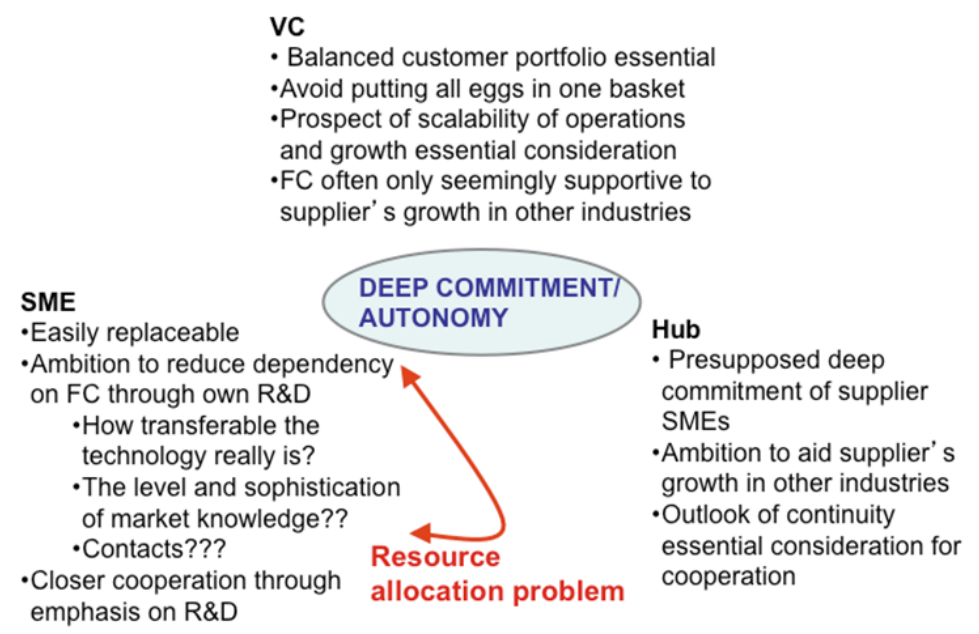

Figure 3. Commitment vs. Autonomy

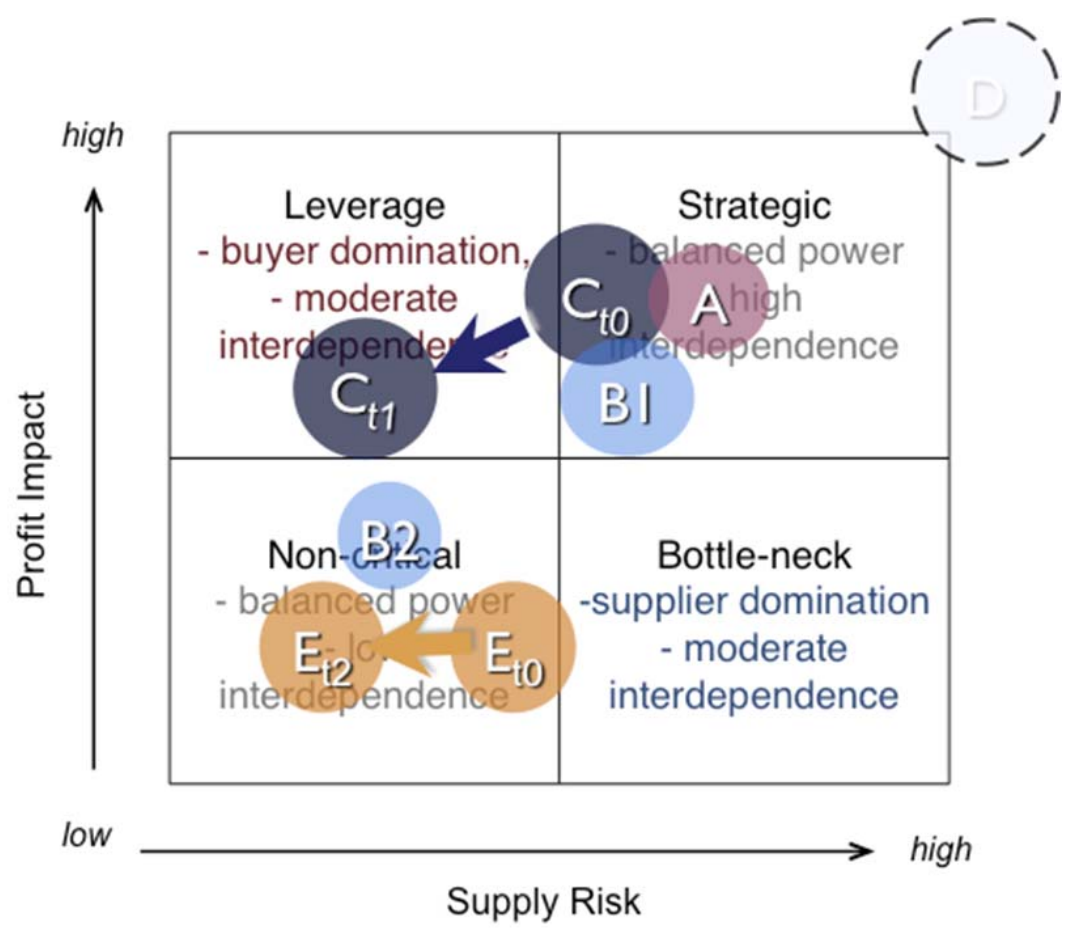

Figure 4. The suppliers position in the Kraljic's matrix. 